\title{
Fish farming impacts in the Mediterranean studied through sediment profiling imagery
}

\author{
Ioannis Karakassis ${ }^{1, *}$, Manolis Tsapakis ${ }^{1}$, Christopher J. Smith ${ }^{1}$, Heye Rumohr ${ }^{2}$ \\ ${ }^{1}$ Institute of Marine Biology of Crete, PO Box 2214, 71003 Heraklion, Crete, Greece \\ ${ }^{2}$ Institut für Meereskunde, Düsternbrooker Weg 20, 24105 Kiel, Germany
}

\begin{abstract}
The sediment beneath and at various distances from the fish farm cages in Cephalonia bay (Eastern Mediterranean) was investigated seasonally through sediment profiling imagery (SPI) as well as through monitoring of geochemical variables and macrofaunal assemblages. The SPI images (SPI) repeatedly showed the same qualitative pattern along the benthic enrichment gradient with readily identifiable attributes such as depth of dark sediment, signs of outgassing and bioturbation marks. Quantitative comparisons showed that a large number of SPI attributes showed significant positive or negative correlation with geochemical and biological attributes describing the effect of fish farming on the seabed. All multivariate patterns obtained through the analysis of SPI attributes were highly correlated to those obtained from standard multivariate analysis of macrofauna during the respective seasons. It is argued that SPI provides an integrated assessment of the sedimentary conditions and therefore may be used as a complement of or even a substitute for standard sampling methods when mapping the effects of aquaculture on silty substrates.
\end{abstract}

KEY WORDS: Sediment profile imaging (SPI) $\cdot$ Benthic habitats $\cdot$ Impacts of aquaculture $\cdot$ Multivariate analysis $\cdot$ Mediterranean

\section{INTRODUCTION}

Among the environmental effects of fish farming, those on benthos are the most commonly found throughout the world (Gowen \& Bradbury 1987, Iwama 1991). The sedimentation of organic material results in an anoxic sediment layer on the seabed beneath the farm cages (Hall et al. 1990, Holmer 1991) with specific geochemical properties such as negative redox values (Hargrave et al. 1993), high organic content (Hall et al. 1990, Holmer 1991, Angel et al. 1995, Karakassis et al. 1998) and accumulation of nitrogenous and phosphorous compounds (Holby \& Hall 1991, Hall et al. 1992). Several studies addressing the effects of fish farming on macrobenthos (Brown et al. 1987, Weston 1990, Hansen et al. 1991, Karakassis et al. 2000) revealed similarities with the empirical succession model of Pearson \& Rosenberg (1978) in terms of the spatial distribution of macrofauna.

\footnotetext{
*E-mail: jkarak@imbc.gr
}

The development of sediment profiling imagery (SPI) and the REMOTS ${ }^{\mathrm{TM}}$ technology (Remote Ecological Monitoring of the Seafloor; Rhoads \& Germano 1982) has made it possible to inspect the upper sediment layers as if through an inverted periscope (Rumohr \& Schomann 1992). SPI has been employed for investigating environmental change along pollution or disturbance gradients (Rhoads \& Germano 1982, 1986, O'Connor et al. 1989, Rumohr \& Schomann 1992, Rosenberg \& Diaz 1993, Rumohr 1993, Nilsson \& Rosenberg 1997). Although SPI methodology has been used in monitoring the impact of fish cages on the seabed for a long time, there is only limited information published in the scientific literature $\left(\mathrm{O}^{\prime}\right.$ Connor et al. 1989, Rumohr et al.1993).

In a number of papers, SPI information has been presented in combination with macrofaunal and/or geochemical data (Rhoads \& Germano 1982, 1986, O'Connor et al. 1989, Grehan et al. 1992, Rumohr \& Schomann 1992, Rosenberg \& Diaz 1993, Rumohr 1993, Bonsdorff et al. 1996, Nilsson \& Rosenberg 1997, 
2000, Rumohr \& Karakassis 1999, Rosenberg et al. 2000). The coupling between these sources of information was mainly based on indices such as the OSI (organism-sediment index) introduced by Rhoads \& Germano (1986) or the BHQ (benthic habitat quality index) developed by Nilsson \& Rosenberg $(1997,2000)$. Both these indices are inevitably subjective since the (arbitrary) weight applied to each SPI attribute determines its contribution to the total index value (Rumohr \& Karakassis 1999). An alternative approach has been used by Rumohr \& Karakassis (1999), where SPI images were treated as multiple variables thus allowing comparisons among sampling stations through standard multivariate techniques, but also comparisons of multivariate patterns obtained through either SPI or analysis of macrofauna. Through this type of analysis, they showed that SPI information is complementary to that obtained through the study of macrofaunal structure, occasionally providing important information on benthic disturbance that is not easily accessible through standard benthic monitoring. In that study, the correlation of the multivariate patterns obtained for SPI showed low correlation to those of macrofauna in time series data in the Baltic.

The aim of the present paper is to compare the information obtained through SPI to that obtained through standard monitoring techniques of macrofaunal and geochemical variables and to exploit the potential for using SPI as a surrogate for monitoring the effects of fish farming on benthos. The use of SPI in the vicinity of fish farms allows for testing the performance of this method in detecting changes in short-distance enrichment gradients. Therefore, the scope of the present paper is broader since its results may also be applicable in other cases with similar types of benthic enrichment.

\section{MATERIALS AND METHODS}

Study area. The Cephalonia fish farm (18 to $20 \mathrm{~m}$ depth) is situated in Cephalonia Bay (Cephalonia, Ionian Sea), a large semi-enclosed bay which is connected to the surrounding marine area by a narrow opening (ca. 3 miles, $5.5 \mathrm{~km}$ ) at the southern part of the bay. The seabed in the entire bay is silty with median grain diameter of ca. $0.02 \mathrm{~mm}$. Reported data from this area include spatio-temporal changes in geochemical variables studied in sediment profiles (Karakassis et al. 1998), seasonal monitoring of macrofauna (Karakassis et al. 2000, Karakassis \& Hatziyanni 2000), effects of fish farming on nutrients and plankton (Pitta et al. 1999, Karakassis et al. 2001), and a description of the recovery process after the cessation of fish farming (Karakassis et al. 1999).

Sediment profiling imagery (SPI). A diver-operated SPI system was used at different distances from the fish cages downstream in the main current direction. The seabed was marked with a distance-calibrated rope. A control site with similar depth and substrate type was established $1 \mathrm{~km}$ upstream. All SPI images were taken by 1 diver following a pre-determined protocol. The analysis of the SPI data was carried out by a quasi 'blindfolded' evaluator using the methodology described in Rumohr \& Karakassis (1999). A large number of attributes identified in the SPI-obtained pictures (Table 1) were treated as quantitative data. One third of these attributes have previously been described in Rumohr \& Karakassis (1999). In addition, further attributes were included if they were persistent features in the data set. The presence/absence (binary)

Table 1. Attributes identified in the SPI images

\begin{tabular}{|c|c|c|}
\hline $\begin{array}{l}\text { Abbre- } \\
\text { viation }\end{array}$ & Attribute & Units \\
\hline BLTD & Depth of light brown layer on the top of the sediment & $\mathrm{cm}$ \\
\hline FSD & Farm sediment depth & $\mathrm{cm}$ \\
\hline BR & Boundary roughness & $\mathrm{cm}$ \\
\hline $\mathrm{PD}$ & Average penetration depth & $\mathrm{cm}$ \\
\hline Ho2 & Depth of second horizon & $\mathrm{cm}$ \\
\hline FS & Coarse black sediment on top & \pm \\
\hline GS & Grey clay sediment & \pm \\
\hline BLT & Light brown layer on the top of the sediment & \pm \\
\hline Cswp & Coarse surface with white particles & \pm \\
\hline FST & Fluffy sediment on top & \pm \\
\hline BSf & Black sediment filling, old macrofaunal burrows \& funnels & \pm \\
\hline DOT & Decaying organics on top & \pm \\
\hline DSC & Deep sulfidic clasts & \pm \\
\hline FT & Fines on top & \pm \\
\hline Vd & Voids & \pm \\
\hline VCSS & Vertical curly structures & \pm \\
\hline $\mathrm{CH} 4$ & Signs of outgassing & \pm \\
\hline Laf & Lacuna with fines & \pm \\
\hline UF & Unused feed pellets & \pm \\
\hline $\mathrm{ChF}$ & Chaotic fabric & \pm \\
\hline VR & Vertical ruptures & \pm \\
\hline $\mathrm{BrP}$ & Brown particles & \pm \\
\hline WP & White particles & \pm \\
\hline BT & Bioturbation marks & \pm \\
\hline $\mathrm{Cc}$ & Capitella-like organisms (very small polychaetes in top layer) & \pm \\
\hline Mgs & Mussel shells & \pm \\
\hline $\mathrm{Bg}$ & Traces of white Beggiatoa-type bacterial mats & \pm \\
\hline TLS & Tube-like structures & \pm \\
\hline
\end{tabular}


data were quantified by calculating the frequency of occurrence of each attribute in the replicated photos obtained at each site in each sampling season. A total of 240 SPI photographs was obtained during the entire sampling period (after discarding ca. $5 \%$ of low quality images: those that were overexposed to light, poorly processed or where the sediment surface had been missed). Among these, 200 SPI images were taken at $0,5,10,25$ and $50 \mathrm{~m}$ from the edge of the cages, as well as at the control site, during 3 sampling periods (October 1996, February 1997, July 1997) with more than 10 photos at each station in each sampling event. These photographs were used in multivariate analysis in order to compare spatial patterns obtained through SPI to those resulting from standard analysis of macrofauna.

Underwater video was also used as an auxiliary means of assessing the macroscopic conditions on the seabed. To this end 2 transects were followed and video-recorded by divers and 2 more transects were recorded using a video camera attached to a BENTHOSMini Rover ${ }^{\mathrm{TM}}$ Remotely Operated Vehicle (ROV).

Geochemical variables. The geochemical data used for comparisons with SPI attributes have been reported by Karakassis et al. (1998) and comprised profiles of redox potential (Eh), sediment organic content through loss on ignition (LOI), sediment water content (SWC), total phosphorus and sediment contents in chlorophyll (Chl a) and phaeopigments (Phaeo). For each of these variables, except for Eh, we used the surface value (taken at 0 to $1 \mathrm{~cm}$ from the sediment surface) as well as the measure of vertical variability in the upper $12 \mathrm{~cm}$ of the sediment. The latter is simply the coefficient of variation ( $\mathrm{CV}[\mathrm{k}])$ calculated as the standard deviation over the mean of a variable $(k)$ at all depths in the core cast (Karakassis et al. 1998). For redox, the values at the surface $\left(\mathrm{Eh}_{0}\right)$ and at $2 \mathrm{~cm}$ from the surface were used $\left(\mathrm{Eh}_{2}\right)$.

Macrofaunal data. Samples were taken by SCUBA divers using sampling cores of $9.5 \mathrm{~cm}$ internal diameter and $15 \mathrm{~cm}$ depth of sediment from the water-sediment interface. Five replicates were taken from each sampling station in order to determine the variability within samples. Sediment samples were sieved in the field through a $0.5 \mathrm{~mm}$ mesh. The retained sediment containing the macrofaunal organisms was preserved in $10 \%$ buffered formalin and Rose Bengal was added for staining the organisms and facilitating sorting. Samples were sorted by hand into major taxa and specimens were identified to species level. Parts of these data have been used in other papers (Karakassis et al. 1999, Hatziyanni et al. 2000) focusing in particular on the effect of fish farming on macrofaunal assemblages in various spatio-temporal scales.

Data analysis. Abundance data of all macrobenthic replicates taken at each station during each sampling cruise were averaged and analysed by means of multidimensional scaling (Field et al. 1982) using the PRIMER software (Clarke \& Warwick 1994). Similarities were calculated on double square root-transformed abundance data by means of the Bray-Curtis similarity index (Bray \& Curtis 1957). SPI data were Zstandardised to avoid the effect of differences in range and also analysed by means of MDS, calculating similarities by means of Euclidean distance (Rumohr \& Karakassis 1999). Analysis of correlation between similarity matrices were performed using the method described in Somerfield \& Clarke (1995). The nonparametric Spearman rank correlation coefficient was used for all correlations between variables.

\section{RESULTS}

\section{Change in sediment attributes in the vicinity of the fish cages identified through SPI}

A set of SPI images illustrating some key features of the benthic environment beneath the fish farms is shown in Fig. 1. Changes in sediment colour were apparent at the stations close to the cages and particularly during the warm months of the year. The dark-coloured sediment (commonly termed 'farm sediment', FS) formed a welldefined layer (Fig. 1a) beneath the cages. This layer changed in depth with season, following the feeding rate, which in turn depends on water temperature. During heavy organic loading, there were apparent signs of outgassing or bubbles in the sediment (Fig. 1a,b) which were probably methane $\left(\mathrm{CH}_{4}\right)$ and/or hydrogen sulphide $\left(\mathrm{H}_{2} \mathrm{~S}\right)$. Traces of white Beggiatoa-type bacterial mats $(\mathrm{Bg})$ were also apparent in a large number of SPI photographs (Fig. 1a,c), without covering the entire surface in any of them, as shown by video inspections. Presence of unused feed pellets (UF) was recorded mainly during July 1997 in a number of images taken at the station beneath the cages. In extreme cases (Fig. 2), the recently accumulated unused feed pellets formed a $4 \mathrm{~cm}$ thick dark brown layer above the 'normal' black FS. Presence of empty mussel shells (Mgs) deposited on the sediment surface were recorded beneath the cages and at a short distance from them. These shells are associated with abundant Mytilus growing on the ropes and floating structures of the cages from which they can fall during cleaning. Mussels are not present in natural populations elsewhere in Cephalonia bay.

The control station as well as the stations at large distance from the cages (Fig. 1g,h,i) had a light brown layer on the top of the sediment (BLT) and obvious bioturbation marks (BT) either in the form of infaunal burrow structures or as visible polychaetes occasionally reaching a depth of $16 \mathrm{~cm}$ from the sediment surface. 
The intermediate stations (a distance of 5 to $25 \mathrm{~m}$ from the cages) were generally characterised by the presence of grey mud with black sediment filling the old macrofaunal burrows and funnels (BSf). The abandoned farming site (Fig. 1e) after 21 mo from the cessation of food supply showed a peculiar structure with a visible well-defined dark layer (FS) that could be attributed to the farming period, and on top of that, a fine brown layer which could be either newly deposited sediment or mats of benthic algae, as suggested by Karakassis et al. (1999) due to high pigment content of the surface sediment.

\section{Comparison of SPI data with univariate geochemical and faunal attributes}

The SPI data were correlated, by means of the Spearman rank correlation coefficient, to the available geochemical and macrofaunal data obtained from the respective stations at the respective dates (Table 2). SPI attributes showed a remarkable number of significant correlations with geochemical data. The depth of the light brown sediment was negatively correlated with $\mathrm{P}$ and CV[P], CV[LOI] and CV[SWC], all having been shown to readily reflect heavy impact from the cage
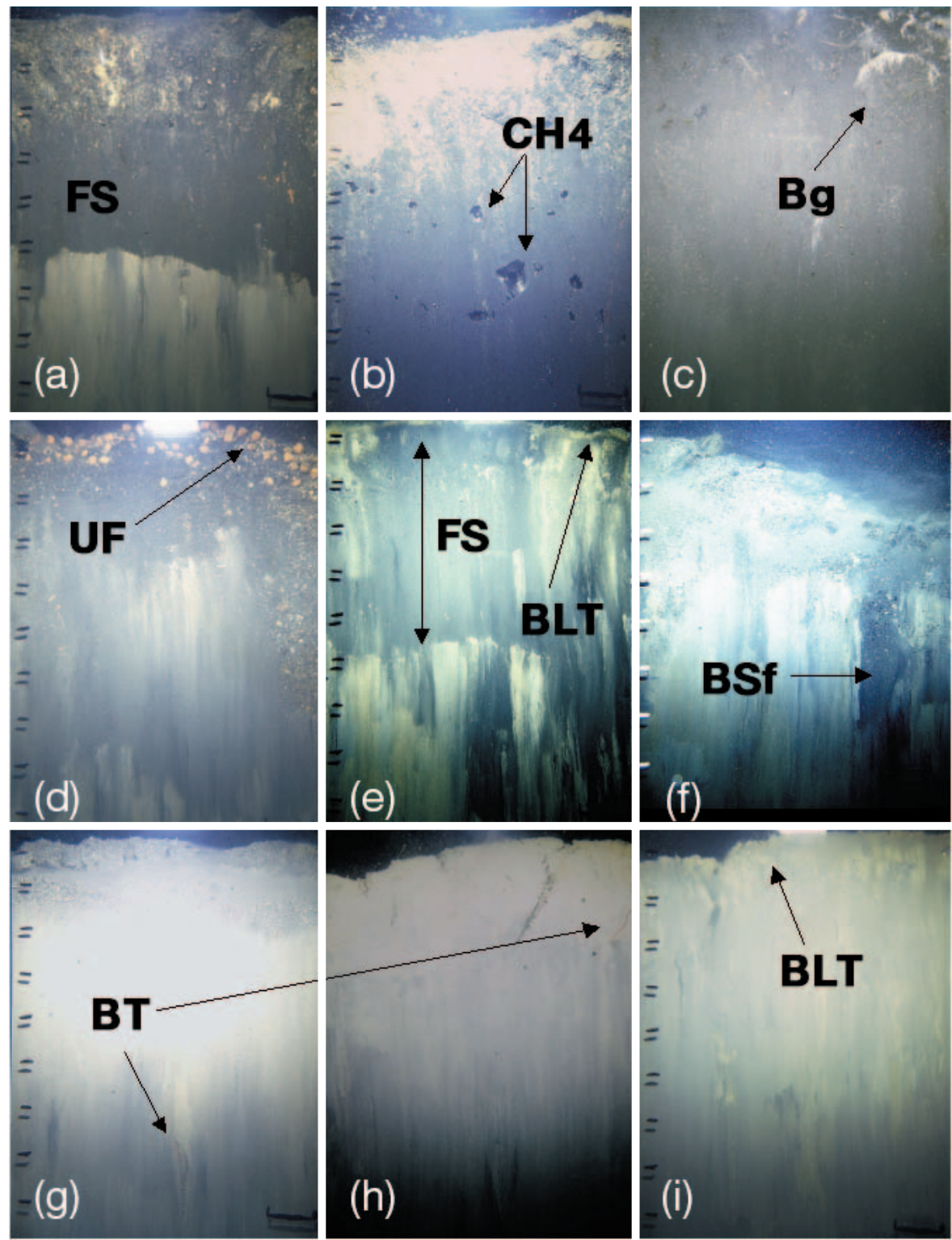

Fig. 1. Examples of SPI images taken beneath the cages $(\mathrm{a}, \mathrm{b}, \mathrm{c}, \mathrm{d})$, at $10 \mathrm{~m}$ from the edge of the cages (f), at an abandoned site (e) and at the control station $(\mathrm{g}, \mathrm{h}, \mathrm{i})$. Visible SPI attributes are marked with symbols as in Table 1

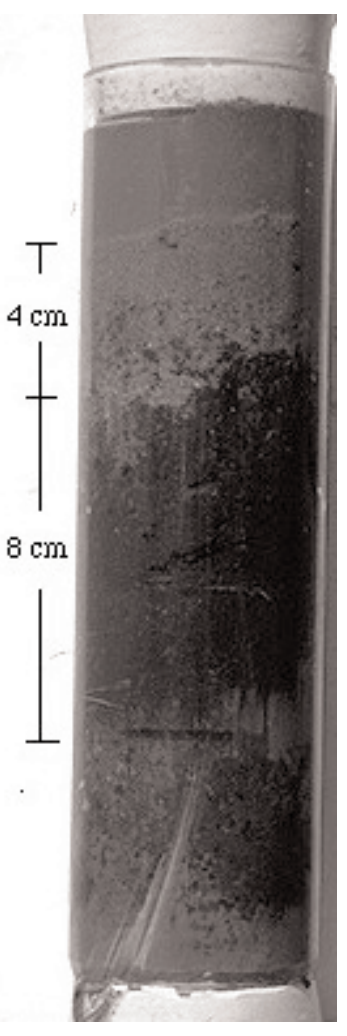

Fig. 2. A core sample taken under the cages (July 1997) showing a recent layer of unused feed on top of the black anoxic sediment accumulated over the entire period of exploitation of the site 
Table 2. Spearman rank correlation coefficients between SPI attributes and macrofaunal and geochemical data. Non-significant values ( $p>0.05)$ and attributes showing no significant correlation to macrofaunal or geochemical values have been omitted. (LOI: loss on ignition, SWC: sediment water content, Chl a: chlorophyll a, Phaeo: phaeopigments, Eh: redox potential at 0 and $2 \mathrm{~cm}$ from sediment surface. SPI abbreviations are explained in Table 1

\begin{tabular}{|c|c|c|c|c|c|c|c|c|c|c|c|c|c|c|}
\hline & $\begin{array}{c}\text { Abund } \\
\mathrm{m}^{-2}\end{array}$ & $\begin{array}{l}\text { Spp } \\
\text { num. }\end{array}$ & $\begin{array}{l}\text { Shannon } \\
\text { index }\end{array}$ & LOI & SWC & Chl a & $\mathrm{P}$ & $\begin{array}{c}\mathrm{CV} \\
{[\mathrm{SWC}]}\end{array}$ & $\begin{array}{c}\mathrm{CV} \\
{[\mathrm{LOI}]}\end{array}$ & $\begin{array}{c}\mathrm{CV} \\
{[\mathrm{Chl} a]}\end{array}$ & $\begin{array}{c}\text { CV } \\
\text { [Phaeo] }\end{array}$ & $\begin{array}{l}\mathrm{CV} \\
{[\mathrm{P}]}\end{array}$ & $\mathrm{Eh}_{0}$ & $\mathrm{Eh}_{2}$ \\
\hline UF & -0.64 & -0.84 & -0.80 & 0.81 & 0.81 & 0.71 & 0.81 & 0.79 & 0.78 & & 0.73 & 0.68 & -0.83 & -0.63 \\
\hline $\mathrm{Bg}$ & -0.68 & -0.83 & -0.78 & 0.78 & 0.78 & 0.69 & 0.82 & 0.78 & 0.76 & & 0.73 & 0.69 & -0.84 & -0.62 \\
\hline FSD & -0.63 & -0.88 & -0.91 & 0.75 & 0.67 & 0.73 & 0.87 & 0.84 & 0.75 & & 0.64 & 0.75 & -0.85 & -0.55 \\
\hline FS & -0.69 & -0.78 & -0.71 & 0.77 & 0.77 & 0.68 & 0.79 & 0.81 & 0.81 & & 0.70 & 0.65 & -0.80 & -0.59 \\
\hline BLT & 0.72 & 0.87 & 0.90 & -0.69 & -0.56 & -0.68 & -0.83 & -0.83 & -0.65 & & -0.60 & -0.80 & 0.83 & 0.52 \\
\hline Ho2 & & -0.63 & -0.61 & 0.73 & 0.73 & 0.66 & 0.61 & 0.72 & 0.75 & & 0.55 & 0.51 & -0.57 & \\
\hline DOT & & -0.64 & -0.66 & 0.76 & 0.76 & 0.61 & 0.66 & 0.66 & 0.73 & & & & -0.59 & \\
\hline CH4 & & -0.64 & -0.66 & 0.76 & 0.76 & 0.61 & 0.66 & 0.66 & 0.73 & & & & -0.59 & \\
\hline BLTD & 0.70 & 0.82 & 0.82 & & & -0.58 & -0.63 & -0.72 & & & -0.51 & -0.63 & 0.72 & \\
\hline $\mathrm{Cc}$ & -0.53 & -0.60 & -0.54 & 0.62 & 0.62 & & 0.71 & 0.62 & 0.66 & & & & -0.66 & \\
\hline VR & & 0.59 & 0.71 & & & -0.53 & -0.71 & & -0.53 & & -0.59 & -0.71 & 0.59 & 0.74 \\
\hline $\mathrm{ChF}$ & -0.59 & -0.64 & -0.57 & & & & 0.52 & 0.51 & & & 0.64 & 0.64 & -0.65 & -0.51 \\
\hline BR & & -0.63 & -0.70 & & & & 0.60 & 0.67 & & & & 0.50 & -0.81 & \\
\hline FT & & & & & & -0.70 & -0.57 & & -0.61 & -0.56 & -0.61 & & & 0.55 \\
\hline PD & & & & & & -0.57 & -0.63 & & & -0.61 & -0.55 & & 0.63 & \\
\hline VCSS & & & & -0.50 & -0.58 & -0.54 & -0.66 & & & & & -0.54 & & \\
\hline TLS & 0.70 & & & -0.71 & -0.62 & & & & & 0.75 & & & & \\
\hline Cswp & & & & 0.57 & 0.57 & & & 0.53 & 0.65 & & & & & \\
\hline FST & & & & 0.57 & 0.57 & & & 0.53 & 0.65 & & & & & \\
\hline GS & & & & -0.62 & -0.80 & & & & & & & & & \\
\hline
\end{tabular}

farms (Karakassis et al. 1998) whereas it correlated positively with redox and benthic diversity. The reverse type of correlation can be seen for the above variables with the depth of the dark sediment (FS) which also seems to integrate information for a wide range of environmental variables. Transformed binary data also showed very significant correlations with chemical and biological data. Presence of outgassing $(\mathrm{CH} 4)$ had a 0.76 coefficient with loss on ignition (LOI) and sediment water content (SWC) and lower but still significant ones with Chl a, sediment phosphorus content $(\mathrm{P})$, surface redox $\left(\mathrm{Eh}_{0}\right)$, and CV[LOI]. From this analysis, it may be inferred which of the variables reflect organic enrichment and which variables are more closely related to the 'healthy' conditions of the seabed.

\section{Multivariate analysis and spatial patterns}

The patterns obtained through the multivariate analysis of SPI data (Fig. 3) showed during all seasons a reasonable succession from the stations under the cages $(0 \mathrm{~m})$ to the control sites. The stress values obtained for the MDS plots were in all cases far lower than 0.1 , indicating that the representation of the data set in 2 dimensions is excellent (Clarke \& Warwick 1994). For the samples taken during the 2 cold seasons, the stations at 5 to $10 \mathrm{~m}$ distance from the cages clustered with the station under the cages and the 25 and $50 \mathrm{~m}$ from the cages clustered with the control site. During July 1997 (after a very mild winter and with an increase in the production of the farm), the conditions under the cages showed considerable signs of degradation so that the station beneath the cages became very dissimilar to the others. During this period, the stations from 5 to $25 \mathrm{~m}$ formed an intermediate cluster which, however, resembled the control site more than the station under the cages.

Standard multivariate analysis of the macrofaunal samples taken at these stations on the same dates showed a very similar 2-dimensional pattern, which has also been detected on other occasions in the same area (Karakassis et al. 2000).

Comparison of SPI dissimilarity matrices to the similarity matrices obtained through macrofaunal analysis (Table 3) showed very high correlation coefficients between data sets obtained during the same sampling period, indicating that the patterns resulting from these 2 independent sources of information are quite similar. The coefficient has negative values for all comparisons between SPI and faunal patterns because these are correlations between similarity and dissimilarity matrices. Furthermore, the patterns obtained during July 1997 had the lowest similarity with the respective patterns of the other 2 seasons in both SPI and macrofauna. It is also worth noting that the faunal and SPI patterns taken during the same season are better correlated to each other than to other patterns obtained with the same method (in other words Fauna-SPI of the same season gives a better correlation than either Fauna-Fauna or SPI-SPI of different seasons). 


\section{DISCUSSION}

The use of SPI is mainly restricted to muddy and silty substrates as it is of only limited use in sandy bottoms due to weak penetration in densely packed sediments. Coastal muddy substrates are widely found on the Mediterranean shelf. The benthic communities in this type of environment have been described by Pérès (1967). Several authors have found more or less similar types of communities in other parts of the Mediterranean (Abello et al. 1988, Karakassis \& Eleftheriou 1997, Zenetos et al. 1997). Shallow coastal bottoms in the Mediterranean are dominated by coarse sediments. However, muddy bottoms have been reported and studied in shallow Mediterranean waters of less than $30 \mathrm{~m}$ (Pancucci-Papadopoulou et al. 1999, Simboura et al. 2000), in the very zone of expansion of the fish farming industry. Sites with silty substrate, as opposed to sandy ones, are far from being ideal for aquaculture (Munday et al. 1992, Karakassis et al. 2000), and it has been suggested (PAP/RAC 1996) that regulating authorities should discourage establishing farms there. However, in many Mediterranean countries the type of substrate is not a criterion for site selection (Papoutsoglou 2000) and the number of farms
Table 3. Pairwise Spearman rank correlations between dissimilarity and similarity matrices derived from cluster analysis of SPI data and macrofaunal abundance data respectively. The figures in bold indicate correlations between SPI and macrofaunal data obtained during the same sampling event

\begin{tabular}{|lcccccc|}
\hline & $\begin{array}{c}\text { Fauna } \\
\text { Oct }\end{array}$ & $\begin{array}{c}\text { Fauna } \\
\text { Feb }\end{array}$ & $\begin{array}{c}\text { Fauna } \\
\text { Jul }\end{array}$ & $\begin{array}{c}\text { SPI } \\
\text { Oct }\end{array}$ & $\begin{array}{c}\text { SPI } \\
\text { Feb }\end{array}$ & $\begin{array}{r}\text { SPI } \\
\text { Jul }\end{array}$ \\
\hline Fauna Oct & 1 & & & & & \\
Fauna Feb & 0.903 & 1 & & & & \\
Fauna Jul & 0.794 & 0.770 & 1 & & & \\
SPI Oct & $\mathbf{- 0 . 9 2 7}$ & -0.782 & -0.794 & 1 & & \\
SPI Feb & -0.939 & $\mathbf{- 0 . 9 2 7}$ & -0.685 & 0.818 & 1 & \\
SPI Jul & -0.442 & -0.527 & $\mathbf{- 0 . 7 9 4}$ & 0.358 & 0.467 & 1 \\
\hline
\end{tabular}

situated in silty areas is expected to be quite high since they provide protection from intense wave action.

Our results indicate that in such conditions the impacted zone is restricted to under the cages and a small distance of a few meters beyond. In this context, this study confirms findings of several other papers around the world (Brown et al. 1987, O'Connor et al 1989, Hansen et al. 1991, Krost et al. 1994, Angel et al 1995, Karakassis et al. 1998, 2000). In addition, it was found that some of the most 'negative effects' (those
Oct

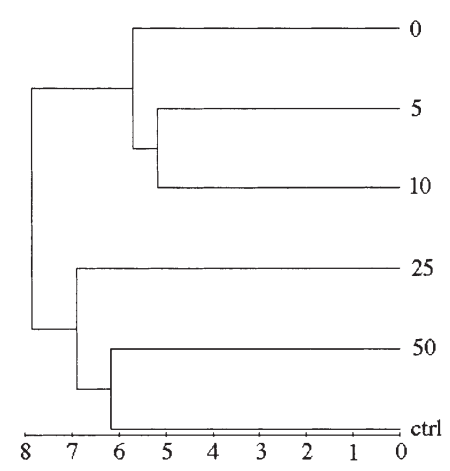

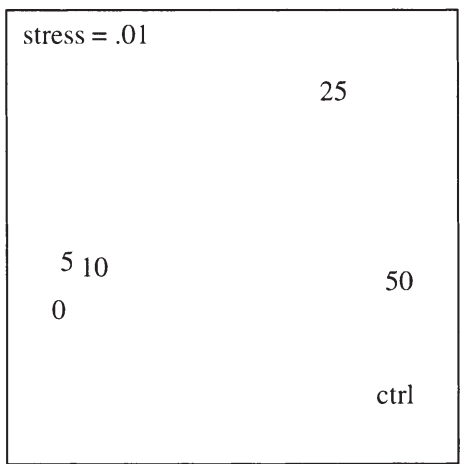

Feb

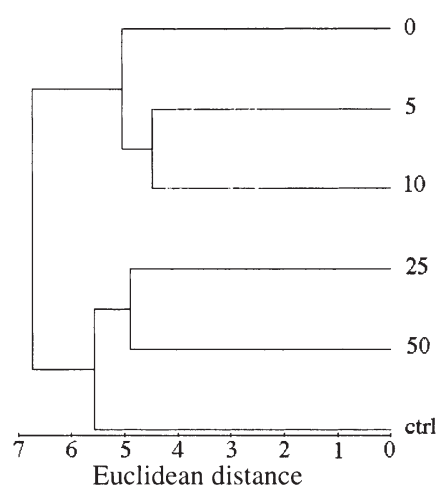

Jul

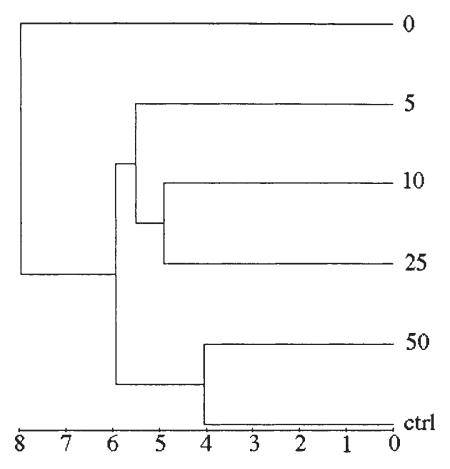

stress $=.00$
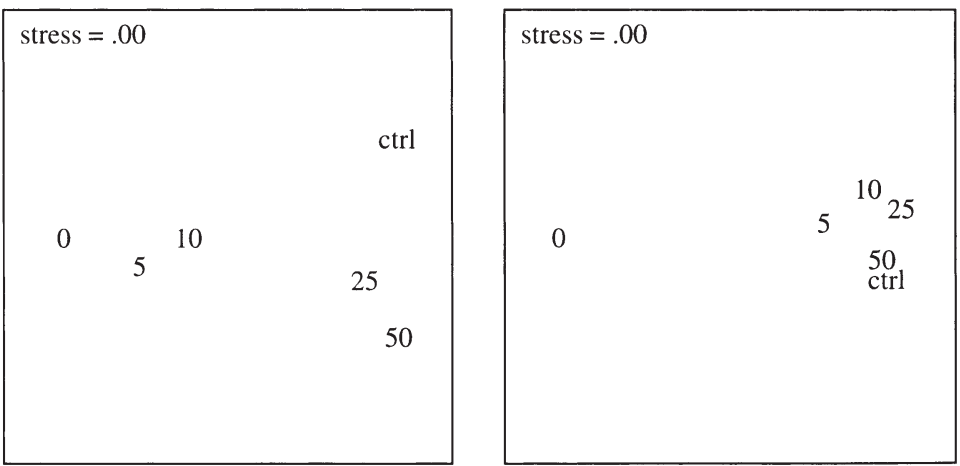

Fig. 3. Multivariate analysis of SPI data taken during 3 seasons beneath the cages $(0 \mathrm{~m})$ at the control site (ctrl) and at various distances (in $\mathrm{m}$ ) from the edge of the cages 
indicating severe change in benthic habitats) such as outgassing signs or traces of Beggiatoa-type mats, were not found even at the $5 \mathrm{~m}$ station and, therefore, it seems reasonable to assume that they are strictly confined to the area immediately receiving the large pellets (faecal or food).

In their mass balance model for carbon and nitrogen, Gowen \& Bradbury (1987) suggested there is a loss of unused feed (ca. $10 \%$ of the quantity supplied), whereas all other papers with such models assumed zero loss of unused feed (Wu 1995). Our survey provided photographic evidence that food pellets could be found intact on the seabed.

Macrofaunal analysis at lower taxonomic resolution has been proposed as a substitute for the standard analysis of species-abundance data (Warwick 1988a,b), particularly when strong pollution gradients are involved. Subsequently, a number of papers have proved the efficiency of these techniques (Ferraro \& Cole 1990, Somerfield \& Clarke 1995, Peterson et al. 1996, Olsgard et al. 1997, 1998, Rumohr \& Karakassis 1999, Karakassis \& Hatziyanni 2000) concluding that in macrofaunal studies surprisingly little information is lost, even if specimens are identified to the level of phylum. These statements were based on comparisons of multivariate patterns obtained through analysis of fauna at different levels of taxonomic resolution to the patterns obtained through the analysis at the species level. Using the same type of comparison, our results showed that very little information is lost when standard analysis at the species level is replaced by SPI. Furthermore, if this type of SPI information loss is compared to that reported for different levels of taxonomic resolution from the Cephalonia fish farm (Karakassis \& Hatziyanni 2000), with a $4^{\text {th }}$ root transformation, it seems that SPI is better than the analysis at the order level and a little worse than the analysis at the family level. The term 'information loss' in this case is used to denote dissimilarity between multivariate patterns and in particular between SPI (or low taxonomic resolution) and that obtained through the analysis at the level of species.

Both methods (SPI and macrofaunal analysis) integrate a large amount of information related to the 'health' of the benthic environment that no single geochemical variable could provide. In this context, it could be argued that SPI should replace monitoring of macrofauna around fish cages situated over silty substrates, taking into account the huge differences in cost between the 2 methods. However, this argument would be perhaps premature, since the 2 methods provide quite different types of results and they have different strengths and weaknesses. SPI monitoring has a much lower cost (by 2 orders of magnitude) than macrofauna, and provides much faster (days-weeks) infor- mation on the vertical structure of the sediment that is not readily provided by the standard methods. However, SPI is not suitable for all kinds of substrates, nor does it give similar patterns to the macrofauna in weak gradients or in time-series data (Rumohr \& Karakassis 1999). On the other hand, both methods are suitable for setting environmental quality standards: macrofaunal species richness is already one such criterion in use in Scotland (Henderson \& Davies 2000) but there is no reason why other criteria could not be used, such as the depth of the farm sediment settling or, particularly, the presence of outgassing which may also be detrimental for the farming industry.

Other rapid methods have been employed for macroassessment of the environmental impacts of fish farming on sandy substrates in the Mediterranean. McDougall \& Black (1999) used acoustic ground discrimination (RoxAnn ${ }^{\mathrm{TM}}$ ) to check whether sediment beneath the cages had different acoustic properties than that in the surrounding area and Papoutsoglou et al. (1996) carried out video transects with divers to detect visible changes on the sediment surface. Both these studies concluded that fish farming had little effect on the seabed. However, it has been shown that video transects in sandy bottoms could show little macroscopic effect while there are significant changes in both geochemical variables (e.g. increase of organic carbon content by a factor of 2 to 3 ) and macrofaunal composition (Karakassis et al. 2000).

Most of the published information regarding SPI, though important, is of a descriptive nature, i.e. with little use of statistical methods, particularly for comparison with other types of environmental data. In a small number of papers, specific SPI attributes, or combinations of them such as OSI, have been compared to various univariate measures of the benthic environment and significant correlations with physical, geochemical or biological variables have been reported (Diaz \& Schaffner 1988, Bonsdorff et al. 1996, Nilsson \& Rosenberg 1997, 2000, Rosenberg et al. 2000). Multivariate analysis of faunal and/or SPI data has also been used in papers involving both types of data (Grizzle \& Penniman 1991, Bonsdorff et al. 1996) but without any statistical comparison between the 2 types of multivariate patterns, with the exception of 1 paper on time-series data from the Baltic (Rumohr \& Karakassis 1999) where a weak correlation was found between SPI and faunal data. The present paper is, therefore, the first to document such a close (and temporally persistent) correlation between multivariate patterns of faunal and SPI data. Further investigation of similarities between spatio-temporal patterns in different regions and types of benthic habitats, subject to different sources of disturbance is needed before generalising the use of SPI as a surrogate for macrofaunal analysis in benthic monitoring. 
The report on monitoring methods for fish farming by GESAMP (1996) recommends analysis of macrofaunal samples as one of the most reliable sources of information despite the high cost involved and the relatively long time needed for processing the samples. Our results indicate that SPI could provide very similar information at very low cost and practically within the sampling day. In this context, it sounds reasonable that SPI could at least replace part of (and preferably in combination with) the standard monitoring as has also been suggested by O'Connor et al. (1989). In a broader context, SPI methodology and the associated multivariate analysis presented here could be used for defining 'grains' (or patches of habitat) within a landscape which is one of the prerequisites for scaling species richness (Gray 2000).

Acknowledgements. The authors would like to thank the manager and the personnel of Cephalonia Fisheries S.A. and in particular Akis Miniatis for their assistance during the sampling, and Eleni Hatziyanni and Wanda Plaiti for assistance with analysis of macrofaunal samples. Thanks are also due to 3 anonymous reviewers for helpful comments on the manuscript. The data were obtained during the project \#565 'Interactions of aquaculture and the marine environment' funded by the Greek General Secretariat for Research and Technology (GSRT) in the framework of the Second Operational Programme for R\&T. Further analysis of the data was made possible through the financial support from the German DRL International Bureau of BMBF and the GSRT in the framework of the Greek-German co-operation agreement in Science and Technology (GRI-044-99).

\section{LITERATURE CITED}

Abello P, Valladares FJ, Castellon A (1988) Analysis of the structure of decapod crustacean assemblages off the Catalan coast (North-West Mediterranean). Mar Biol 98:39-49

Angel DL, Krost P, Gordin H (1995) Benthic implications of the net cage aquaculture in the oligotrophic Gulf of Aqaba. In: Rosenthal H, Moav B, Gordin H (eds) Improving the knowledge base in modern aquaculture. Eur Acuacult Soc Spec Publ 25:129-173

Bonsdorff E, Diaz RJ, Rosenberg R, Norkko A, Cutter GR Jr (1996) Characterization of soft bottom benthic habitats of the Aaland islands, northern Baltic Sea. Mar Ecol Prog Ser 142:235-245

Bray JR, Curtis JT (1957) An ordination of the upland forest communities of southern Wisconsin. Ecol Monogr 27: 325-349

Brown JR, Gowen RJ, McLusky DM (1987) The effects of salmon farming on the benthos of a Scottish sea loch. J Exp Mar Biol Ecol 109:39-51

Clarke KR, Warwick RM (1994) Change in marine communities: an approach to statistical analysis and interpretation. Natural Environment Research Council, UK

Diaz RJ, Schaffner LC (1988) Comparison of sediment landscapes in Chesapeake Bay as seen by surface and profile imaging. In: Lynch MP, Krome EC (eds) Understanding the estuary: advances in Chesapeake Bay research, Publ 129, CBP/TRS 24/88. Chesapeake Research Consortium, Solomons, MD, p 222-240
Ferraro SP, Cole FA (1990) Taxonomic level and sample size sufficient for assessing pollution impacts on the Southern California Bight macrobenthos. Mar Ecol Prog Ser 67: 251-262

Field JG, Clarke KR, Warwick RM (1982) A practical strategy for analysing multispecies distribution patterns. Mar Ecol Prog Ser 8:37-52

GESAMP (IMO/FAO/UNESCO IOC/WMO/IEEA/UN/UNEP Joint Group of Experts on the Scientific Aspects of Marine Environmental Protection) (1996) Monitoring the ecological effects of coastal aquaculture wastes. Rep Stud GESAMP 57:1-38

Gowen RJ, Bradbury NB (1987) The ecological impact of salmonid farming in coastal waters: a review. Oceanogr Mar Biol Annu Rev 25:563-575

Gray JS (2000) The measurement of marine species diversity, with an application to the benthic fauna of the Norwegian continental shelf. J Exp Mar Biol Ecol 250:23-49

Grehan AJ, Keegan BF, Bhaud M, Guille A (1992) Sediment profile imaging of soft substrates in the western Mediterranean; the extent and importance of faunal reworking. CR Acad Sci Paris III-VIE 315:309-315

Grizzle RE, Penniman CA (1991) Effects of organic enrichment on estuarine macrofaunal benthos: a comparison of sediment profile imaging and traditional methods. Mar Ecol Prog Ser 74:249-262

Hall POJ, Anderson LG, Holby O, Kollberg S, Samuelsson MO (1990) Chemical fluxes and mass balances in a marine fish cage farm. I. Carbon. Mar Ecol Prog Ser 61:61-73

Hall POJ, Holby O, Kollberg S, Samuelsson MO (1992) Chemical fluxes and mass balances in a marine fish cage farm. IV. Nitrogen. Mar Ecol Prog Ser 89:81-91

Hansen PK, Pittman K, Ervik A (1991) Organic waste from marine fish farms - effects on the seabed. In: Mäkinen T (ed) Marine aquaculture and environment. Nordic Council of Ministers, Copenhagen, pp 105-119

Hargrave BT, Duplisea DE, Pdeiffer E, Wildish DJ (1993) Seasonal changes in benthic fluxes of dissolved oxygen and ammonium associated with marine cultured Atlantic salmon. Mar Ecol Prog Ser 96:249-157

Hatziyanni E, Tsapakis E, Plaiti W, Karakassis I (2000) Impact of the organic enrichment on the vertical distribution and the size of macrofauna in a coastal fish farming site. Proc 6th Hel Symp Oceanogr Fish 2:341-345

Henderson AR, Davies IM (2000) Review of aquaculture, its regulation and monitoring in Scotland. J Appl Ichthyol 16: 200-208

Holby O, Hall POJ (1991) Chemical fluxes and mass balances in a marine fish cage farm. II. Phosphorus. Mar Ecol Prog Ser 70:263-272

Holmer M (1991) Impacts of aquaculture on surrounding sediments: generation of organic-rich sediments. In: De Pauw $\mathrm{N}$, Joyce J (eds) Aquaculture and the environment. Eur Aquacult Soc Spec Publ 16:155-175

Iwama GI (1991) Interactions between aquaculture and the environment. Crit Rev Environ Control, 21:177-216

Karakassis I, Eleftheriou A (1997) The continental shelf of Crete: structure of macrobenthic communities. Mar Ecol Prog Ser 160:185-196

Karakassis I, Hatziyanni E (2000) Benthic disturbance due to fish farming analyzed under different levels of taxonomic resolution. Mar Ecol Prog Ser 203:247-253

Karakassis I, Tsapakis M, Hatziyanni E (1998) Seasonal variability in sediment profiles beneath fish farm cages in the Mediterranean. Mar Ecol Prog Ser 162:243-252

Karakassis I, Hatziyanni E, Tsapakis M, Plaiti W (1999) Benthic recovery following cessation of fish farming: a series 
of successes and catastrophes. Mar Ecol Prog Ser 184: 205-218

Karakassis I, Tsapakis M, Hatziyanni E, Papadopoulou KN, Plaiti W (2000) Impact of cage farming of fish on the seabed in three Mediterranean coastal areas. ICES J Mar Sci 57: 1462-1471

Karakassis I, Tsapakis M, Hatziyanni E, Pitta P (2001) Diel variation of nutrients and chlorophyll in sea bream and sea bass cages in the Mediterranean. Fresenius Environ Bull 10:278-283

Krost P, Chrzan T, Schomann H, Rosenthal H (1994) Effects of a floating fish farm in Kiel Fjord on the sediment. J Appl Ichthyol 10:354-361

McDougall N, Black KD (1999) Determining sediment properties around a marine cage farm using acoustic ground discrimination: RoxAnn ${ }^{\mathrm{TM}}$. Aquacult Res 30:451-458

Munday B, Eleftheriou A, Kentouri M, Divanach P (1992) The interactions of aquaculture and the environment. A bibliographical review. Commission of the European Communities. Dir Gen for Fisheries, Brussels, p 325

Nilsson HC, Rosenberg R (1997) Benthic habitat quality assessment of an oxygen stressed fjord by surface and sediment profile images. J Mar Syst 11:249-264

Nilsson HC, Rosenberg R (2000) Succession in marine benthic habitats and fauna in response to oxygen deficiency: analysed by sediment profile-imaging and by grab samples. Mar Ecol Prog Ser 197:139-149

O'Connor BDS, Costelloe J, Keegan BF, Rhoads DC (1989) The use of REMOTS technology in monitoring coastal enrichment resulting from mariculture. Mar Pollut Bull 20: 384-390

Olsgard F, Somerfield PJ, Carr MR (1997) Relationships between taxonomic resolution and data transformations in analyses of a macrobenthic community along an established pollution gradient. Mar Ecol Prog Ser 149: 173-181

Olsgard F, Somerfield PJ, Carr MR (1998) Relationships between taxonomic resolution, macrobenthic community patterns and disturbance. Mar Ecol Prog Ser 172:25-36

Pancucci-Papadopoulou MA, Simboura N, Zenetos A, Tziavos C (1999) Benthic invertebrate communities of NW Rodos (Rhodes) Island (SE Aegean Sea) as related to hydrological regime and geographical location. Isr J Zool 45: 371-393

Papoutsoglou SE (2000) Monitoring and regulations of marine aquaculture in Greece: licensing, regulatory control and monitoring guidelines and procedures. J Appl Ichthyol 16: $167-171$

Papoutsoglou S, Costello MJ, Stamou E, Tziha G (1996) Environmental conditions at sea-cages and ectoparasites on farmed European sea-bass, Dicentrarchus labrax (L.) and gilt-head sea-bream, Sparus aurata L., at two farms in Greece. Aquacult Res 27:25-34

PAP/RAC (1996) Approaches for zoning of coastal areas with reference to Mediterranean aquaculture. PAP-10/EAM/ GL.2, Split, Croatia, p 35

Pearson TH, Rosenberg R (1978) Macrobenthic succession in relation to organic enrichment and pollution of the marine environment. Oceanogr Mar Biol Annu Rev 16:229-311

Pérès JM (1967) The Mediterranean benthos. Oceanogr Mar Biol Annu Rev 5:449-533

Peterson CH, Kennicutt MC, Green RH, Montagna P, Harper
DE, Powell EN, Roscigno PF (1996) Ecological consequences of environmental perturbations associated with offshore hydrocarbon production: A perspective on longterm exposures in the Gulf of Mexico. Can J Fish Aquat Sci 53:2637-2654

Pitta P, Karakassis I, Tsapakis M, Zivanovic S (1999) Natural versus mariculture induced variability in nutrients and plankton in the Eastern Mediterranean. Hydrobiologia 391:181-194

Rhoads DC, Germano JD (1982) Characterization of organismsediment relations using sediment profile imaging: an efficient method of Remote Ecological Monitoring of the Seafloor (REMOTS ${ }^{\text {TM }}$ System). Mar Ecol Prog Ser 8:115-128

Rhoads DC, Germano JD (1986) Interpreting long-term changes in benthic community structure: a new protocol. Hydrobiologia 142:291-308

Rosenberg R, Diaz RJ (1993) Sulfur bacteria (Beggiatoa spp.) mats indicate hypoxic conditions in the inner Stockholm archipelago. Ambio 22:32-36

Rosenberg R, Nilsson HC, Hellman B, Agrenius S (2000) Depth correlated benthic faunal quantity and infaunal burrow structures on the slopes of a marine depression. Estuar Coast Shelf Sci 50:843-853

Rumohr H (1993) Erfahrungen und Ergebnisse aus 7 Jahren Benthosmonitoring in der südlichen Ostsee. In: Duinker JC (ed) Das Biologische Monitoring der Ostsee im Institut für Meereskunde Kiel 1985-1992, Berichte IfM 240, p 90-109

Rumohr H, Schomann H (1992) REMOTS sediment profiles around an exploratory drilling rig in the southern North Sea. Mar Ecol Prog Ser 91:303-311

Rumohr H, Karakassis I (1999) Comparison of multivariate patterns: different taxonomic levels in macrofaunal analysis versus sediment profiling imagery (SPI). Mar Ecol Prog Ser 190:125-132

Rumohr H, Angel D, Krost P, Zuber D (1993) The environmental impact of fish cage cultures in Eilat, Gulf of Aqaba (Israel). In: Eleftheriou A (ed) The 28th European Marine Biology Symposium-Book of Abstracts, Hersonissos, Crete, p 65

Simboura N, Nicolaidou A, Thessalou-Legaki M (2000) Polychaete communities of Greece: An ecological overview. Mar Ecol 21:129-144

Somerfield PJ, Clarke KR (1995) Taxonomic levels in marine community studies, revisited. Mar Ecol Prog Ser 127: 113-119

Warwick RM (1988a) The level of taxonomic discrimination required to detect pollution effects on marine benthic communities. Mar Pollut Bull 19:259-268

Warwick RM (1988b) Analysis of community attributes of the macrobenthos of Frierfjord/Langesundfjord at taxonomic levels higher than species. Mar Ecol Prog Ser 46:167-170

Weston DP (1990) Quantitative examination of macrobenthic community changes along an organic enrichment gradient. Mar Ecol Prog Ser 61:233-244

Wu RSS (1995) The environmental impact of marine fish culture: Towards a sustainable future. Mar Pollut Bull 31: 159-166

Zenetos A, Christianidis S, Pancucci MA, Simboura N, Tziavos C (1997) Oceanologic study of an open coastal area in the Ionian Sea with emphasis on its benthic fauna and some zoogeographical remarks. Oceanol Acta 20:437-451

Submitted: December 12, 2000, Accepted: June 21, 2001

Proofs received from author(s): January 28, 2002 